Article

\title{
Essential Oil Content of Baccharis crispa Spreng. Regulated by Water Stress and Seasonal Variation
}

\author{
Maria Alejandra Moreno-Pizani $1, * \mathbb{C}$, Franklin Javier Paredes-Trejo ${ }^{2}{ }^{(1)}$, \\ Asdrubal Jesus Farias-Ramirez ${ }^{1}$, Hugo Thaner dos Santos ${ }^{3}$, Adna Prado Massarioli ${ }^{4}$, \\ Fabio Ricardo Marin ${ }^{5}{ }^{\circ}$, Bruno Yukio Takeyoshi ${ }^{5}$, Patricia Angelica Alves Marques ${ }^{5}{ }^{(0)}$, \\ Sônia Maria De Stefano Piedade ${ }^{5,6}$ and Severino Matias de Alencar ${ }^{4}$ (i) \\ 1 Faculdade Pecege, Programa de Educação Continuada em Economia e Gestão de Empresas (PECEGE), \\ Piracicaba-SP 13418-445, Brazil; ajfara@gmail.com \\ 2 Department of Civil Engineering, University of the Western Plains Ezequiel Zamora (UNELLEZ), \\ San Carlos Campus 2311, Venezuela; franklinparedes75@gmail.com \\ 3 Agricultural Engineering Department, Federal University of Vicosa (UFV-DEA), \\ Vicosa-MG 36570-900, Brazil; hthaner@gmail.com \\ 4 Department of Agri-Food Industry, Food and Nutrition, 'Luiz de Queiroz' College of \\ Agriculture, (ESALQ-LAN), University of São Paulo, Piracicaba-SP 13418-900, Brazil; \\ adnaprado@usp.br (A.P.M.); smalencar@usp.br (S.M.d.A.) \\ 5 Biosystems Engineering Department (ESALQ-LEB), University of Sao Paulo, Piracicaba-SP 13418-900, Brazil; \\ fabio.marin@usp.br (F.R.M.); brunotakeyoshi@gmail.com (B.Y.T.); paamarques@usp.br (P.A.A.M.); \\ soniamsp@usp.br (S.M.D.S.P.) \\ 6 Department of Math, Chemistry and Statistics Department (ESALQ-LCE), University of São Paulo, \\ Piracicaba-SP 13418-900, Brazil \\ * Correspondence: morenom76@gmail.com; Tel.: +55-19-3377-0937 (ext. 288)
}

Received: 7 July 2020; Accepted: 29 July 2020; Published: 8 August 2020

\begin{abstract}
Carqueja (Baccharis crispa Spreng.) has been primarily used as a medicinal plant around the world. Commercially, the essential oil content of carqueja leaves is the most valuable crop productivity variable. We evaluated the effect of irrigation management in different growing seasons on the essential oil content of carqueja leaves using gas chromatography coupled with mass spectrometry. The experiment was conducted in a greenhouse located in Southern Brazil, where the crop was cultivated for two years in different growing seasons under six irrigation regimes: $25 \%, 50 \%, 75 \%$, $100 \%, 125 \%$, and $150 \%$ of the reference crop evapotranspiration (T25, T50, T75, T100, T125, and T150, respectively). A seasonal pattern was observed in the number of metabolites of sesquiterpenes and phenolics in the essential oil extracted from the biomass; this outcome was correlated with irrigation regimes and air temperature. Principal component and hierarchical cluster analyses were used to discriminate the influence of abiotic conditions on secondary metabolite profiles. Spathulenol was the most abundant compound in the essential oils $(95.43 \%)$ collected during the summer (December-March) season during the third harvest (H3) at T150. The essential oil content was $8.84 \% \pm 0.05 \%$ and $10.52 \% \pm 0.10 \%$ in summer and winter (June-September), respectively, with T100 at 45 and 46 days after planting.
\end{abstract}

Keywords: carqueja; oil content; irrigation schedule; GC-MS

\section{Introduction}

Baccharis species have been extensively used for industrial purposes as well as in food and beverages, mainly in South America and Japan [1]. The literature shows that Baccharis species have also been useful for human health and in preventing heart disease and cancer, treating rheumatism 
and rheumatoid arthritis, and to ameliorate gastrointestinal, hepatic, and renal diseases, in addition to inflammatory disorders [2-9].

These properties have led to attention being focused on the oil components of Baccharis species. Earlier investigations reported the presence of bitter sesquiterpenoids [8], and that soil and weather conditions can influence the chemical composition of wild and cultivated Baccharis species [6].

The water status of plants affects their functions and metabolic processes, and their essential oil yields are responsive to the severity and duration of water stress [10]. High water stress levels affect oil yield in many aromatic plants [11,12]. Metabolites and essential oil yields in different medicinal and aromatic plants decrease under water-stress conditions $[10,13-16]$ and reduced irrigation frequency $[11,12,17]$. B. crispa is popularly recognized as carqueja in Brazil, and grows spontaneously in a wide range of soils and ecosystems in different Brazilian bioclimatic zones [18]. It is currently used as a medicinal plant and requires strict irrigation management to ensure a high yield and optimal quality in commercial farming systems [12].

Optimal irrigation management requires working knowledge. To provide such knowledge on the quality of $B$. crispa (carqueja), grown in tropical environment for medicinal purposes to farmers and companies, we aimed to identify all the essential oil components (EOC) in carqueja using gas chromatography coupled with mass spectrometry (GC-MS), as well as to compare the essential oil yields and dry matter production of B. crispa (carqueja) from a wide range of irrigation regimes with different crop growing seasons.

\section{Materials and Methods}

\subsection{Plant Material}

Two experiments were conducted with B. crispa, cultivated from 28 September 2015 to 7 November 2016 in a greenhouse at the Department of Biosystems Engineering of ESALQ/USP in Piracicaba, SP $\left(22^{\circ} 42^{\prime} \mathrm{S}, 47^{\circ} 38^{\prime} \mathrm{W}, 546 \mathrm{~m}\right.$ above sea level). We prepared the botanical material collection and exsiccate production for further inclusion into the collection of the Herbarium at the Botany Department of the Federal University of Paraná (registered as UPCB 86437). The material in the first experiment (summer: December-March) was harvested at 45, 95, and 205 days after planting (DAP) by cutting from the plant shoot (15 cm above the ground). The plant shoots were harvested at 46, 119, and $182 \mathrm{DAP}$, and the dry biomass was determined in the second experiment (winter: June-September). The soil used in the experiments was classified as typical eutrophic red latosol in Brazil [19] and as typic hapludox in the United States [20].

\subsection{Water Deficit Treatments}

A completely randomized block design was used to simulate the different soil and climate conditions. This design consisted of six treatments with six repetitions, totaling 36 plots. Each $11 \mathrm{~L}$ pot with one carqueja plant corresponded to one plot. Treatments consisted of six irrigation regimes based on the reference crop's evapotranspiration (ETo) (the FAO Penman-Monteith approach [21]) values: T100 optimal irrigation regime (applying 100\% ETo); T75, T50, and T25 sustained deficit irrigation regimes (applying 75\%, 50\%, and 25\% ETo, respectively); and T125 and T150 excessive irrigation regimes (applying 125\% and 150\% ETo, respectively). A Campbell Scientific CR23X data logger was used for controlling the meteorological station installed in the center of the greenhouse.

\subsection{Extraction of the Essential Oil (EO)}

Leaves of B. crispa were oven dried at $40 \pm 3{ }^{\circ} \mathrm{C}$ under air circulation for $48 \mathrm{~h}$. The essential oil was extracted from the dried shoot samples $(100 \pm 0.1 \mathrm{~g})$. Extraction was carried out in $2 \mathrm{~L}$ of distilled water through hydrodistillation in a Clevenger-type apparatus for $3 \mathrm{~h}$ (until all the essential oil was extracted) [22,23]. The extracted essential oils were then collected, placed in clean and sealed brown 
glass vials, and stored in a cool $\left(4^{\circ} \mathrm{C}\right)$ and dry place for further tests [24,25]. The essential oil yield (\%) was calculated as the essential oil mass (g) divided by the dry shoot mass (g) [26,27].

\subsection{Gas Chromatography-Mass Spectrometry (GC-MS) Analysis}

GC-MS analyses of the EO were performed using a gas chromatograph GC 2010 (Shimadzu Corp., Kyoto, Japan) coupled to a mass spectrometer QP 2010 Plus (Shimadzu Corp., Kyoto, Japan). A $0.5 \mu \mathrm{L}$ aliquot of non-diluted EO was injected in splitless mode. Separation was achieved on a Rtx ${ }^{\circledR}-5 \mathrm{MS}$ (5\% diphenyl $/ 95 \%$ dimethyl polysiloxane, $30 \mathrm{~m} \times 0.25 \mathrm{~mm}$ with a $0.25 \mu \mathrm{m}$ film thickness (Teknokroma Analitica, SA, Barcelona, Spain) fused silica capillary column, using helium as a carrier gas at a constant flow rate of $36.8 \mathrm{~cm} / \mathrm{s}$ ). The initial oven temperature of $40^{\circ} \mathrm{C}$ (held for $5 \mathrm{~min}$ ) was increased to $250{ }^{\circ} \mathrm{C}$ at $5{ }^{\circ} \mathrm{C} / \mathrm{min}$ and then up to $290^{\circ} \mathrm{C}$ at $10^{\circ} \mathrm{C} / \mathrm{min}$, and held at that temperature for $15 \mathrm{~min}$ for a total run time of $47 \mathrm{~min}$. The quadrupole mass spectrometer was operated in the electron ionization mode at $70 \mathrm{eV}$ with a source temperature of $230{ }^{\circ} \mathrm{C}$ and in the quadrupole mode at $200{ }^{\circ} \mathrm{C}$ with a scan range $\mathrm{m} / \mathrm{z}$ 20-550. Oil components were identified by the comparison of their mass spectra and retention times with those of the C9-C20 n-alkanes and MS data deposited in the Wiley Spectroteca (Wiley 07) and the Flavors and Fragrances of Natural and Synthetic Compounds (FFNSC 1.3) databases. The samples were injected in triplicate [28].

\subsection{Statistical Analysis}

Principal component analysis (PCA) was performed using R software [29] to assess the interrelations between the environmental conditions and the essential oil compounds of leaves according to their harvest collection time and different irrigation regimes [30]. Hierarchical cluster analysis (HCA) was applied to investigate sample similarity based on the distribution of essential oil constituents. HCA was used to validate the PCA analysis. Pearson's correlation analysis was used to verify the possible linear association between the essential oil compounds and weather variables.

\section{Results and Discussion}

\subsection{Environmental Data}

According to de Bona et al., and Fachinello et al. [9,31], increasing temperature facilitates cell division; however, it may also cause excessive sweating on herbaceous and semi-evergreen cuttings as well as budding without rooting, which is an undesirable outcome for B. crispa. The literature review showed a lack of information on the basal temperature of this crop. The minimum and maximum air temperatures at the end of the autumn (March-June) and winter (June-September) experimental periods were 2.38 and $41.13{ }^{\circ} \mathrm{C}$, respectively, while the mean relative humidity reached $74.94 \%$.

However, the recorded minimum temperature values, mainly those recorded in June and July 2016, reached the lower limit set in Andrião [32] for the desired thermal amplitude of this crop. Burmeister and Guttenberg [33] reported that the production of essential oils in medicinal plants is an exothermic process; thus, the ambient air temperature is a variable that regulates this secondary metabolic process. Dos Santos et al. and García $[1,34]$ noted a reduction in the $B$. trimera essential oil content as the temperature decreased while the content increased with temperature. Figure 1 shows the response of the mean dry biomass production of $B$. crispa (carqueja) to a wide range of six irrigation regimes based on the reference crop evapotranspiration (ETo) values. 


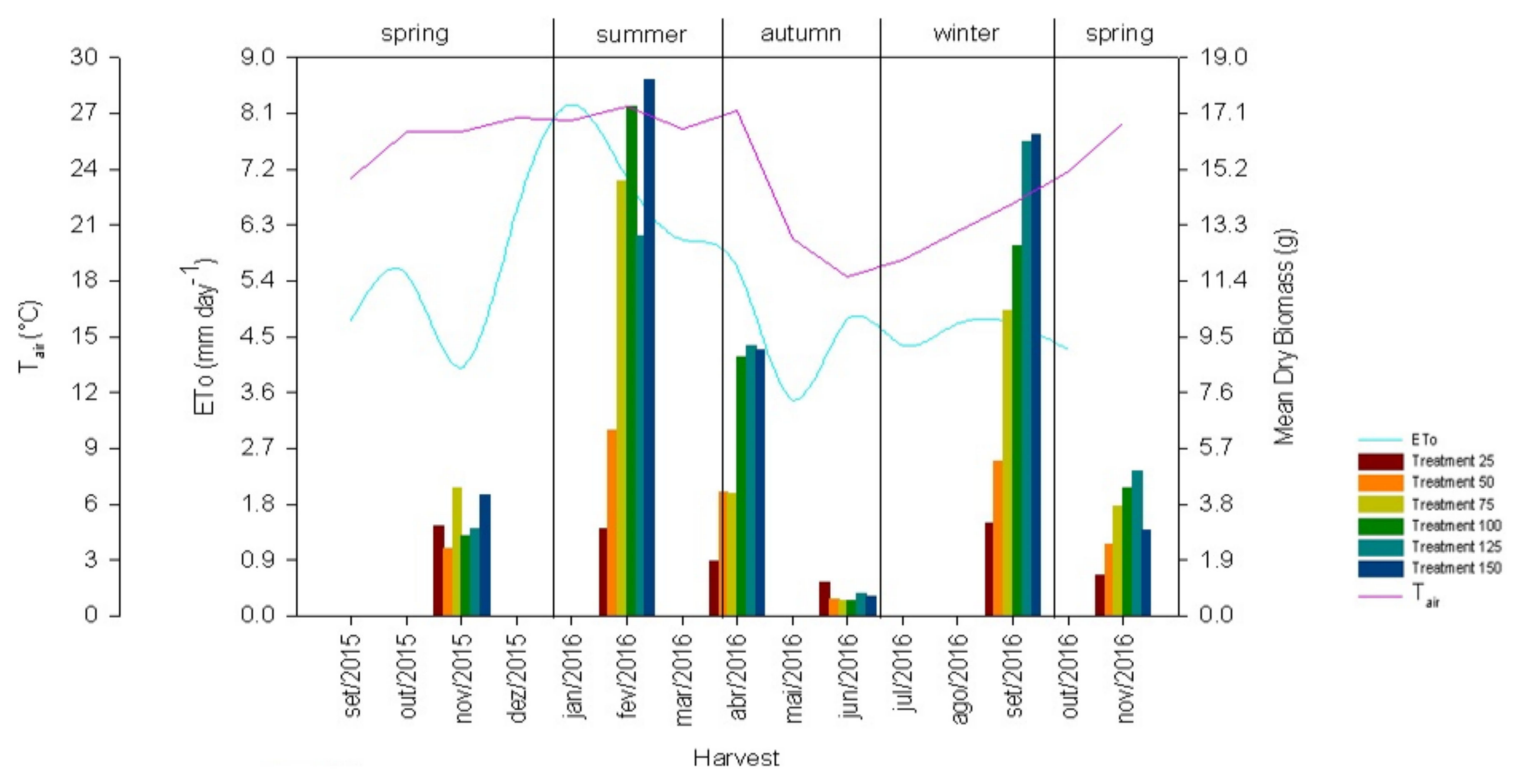

Figure 1. Air temperature $\left(\mathrm{T}_{\text {air }}\right)$, evapotranspiration of reference (ETo), and mean dry biomass for treatment according to the six irrigation regimes: T100 optimal irrigation regime (applying 100\% ETo); T75, T50, and T25 sustained the deficit irrigation regimes, applying 75\%, 50\%, and 25\% ETo, while T125 and T150 represented excess irrigation regimes (applying 125\% and 150\% ETo) in different crop-growing seasons.

\subsection{Essential Oil Components}

Essential oil components (EOC) (expressed as dry weight) were equal to $8.84 \% \pm 0.05 \%$ and $10.52 \% \pm 0.10 \%$ in summer (December-March) and winter (June-September), respectively, and 100\% ETo (fully irrigated condition) at 45 and 46 DAP. These results are not in agreement with those reported earlier for the EOC of B. trimera leaves (3.00\%) in winter (June-September) in Paraná State, Brazil [35], in which a $0.05 \%$ essential oil yield was reported for the leaves of $B$. trimera cultivar CPQBA 1 [5]. In another study, B. dracunculifolia DC was reported to have the highest essential oil content $(0.8 \% \pm 0.1 \%)$, followed by B. cylindrica (Less.) DC $(0.6 \% \pm 0.0 \%)$, B. articulata (Lam.) Pers. $(0.5 \% \pm 0.0 \%)$, and B. gaudichaudiana DC $(0.1 \% \pm 0.0 \%)$ [36]. Variations in the content of essential oils have been related to the genetic patterns of species as well as seasonal conditions and environmental factors that influence plant development [37]. Some compounds are unique to these species, and hence, can be used as chemical markers for species identification and authentication. $\beta$-Pinene and limonene were shown to be major compounds in B. pauciflosculosa. $\alpha$-Bisabolol was found only in B. punctulata. B. reticularioides was shown to contain $\alpha$-pinene, while $\alpha$-pinene, $\beta$-pinene, limonene, and spathulenol were the major compounds in B. sphenophylla [38]. Another study reported lower essential oil yield (1.0\%) at the full flowering stage in Paraná State (Southern Brazil) [39,40] and 0.0591\% yield under 100\% solar radiation in Minas Gerais State (Southeastern Brazil) [9]. Using the grinding method, a $0.56 \%$ yield of the essential oil of B. articulata (Lam.) Pers. was obtained in the analysis [41]. According to Zribi et al. [42], the differences in essential oil yield can be attributed to environmental conditions and different maturity and growth stages. Essential oil content and the composition of essential oils in aromatic plants are affected by environmental conditions [12]. Water deficit decreased the growth, water potential, and plant biomass of S. officinalis shoots, as well as its fatty acid content, but such deficits increased the essential oil yield [11]. Moderate irrigation regimes resulted in higher EOC content in rose-scented geranium (Pelargonium graveolens L.), whereas water deficit was more favorable for essential oil biosynthesis in plants compared to thorough watering treatments [43]. To the authors' best knowledge, this is the first report on the yield of essential oil extracted from Brazilian B. crispa shoots. 


\subsection{Differences in Content and Composition of Essential Oils between the Three Harvest Times}

Forty-eight (48) components were identified during the two assessed seasons under the six irrigation replacement levels. A number of volatiles identified in the current study have not previously been reported for this Baccharis species. The identified volatiles accounted for $97.10 \%, 93.09 \%, 96.04 \%$, $96.46 \%, 90.02 \%$, and $83.22 \%$ of the total volatile constituents in essential oils at $25 \%, 50 \%, 75 \%, 100 \%$, $125 \%$, and $150 \%$ ETo of the reference treatments, respectively (Tables S1-S3, Supplementary Materials). There were differences in the number of identified volatile compounds in comparison to the values in the literature. In a study carried out in Southern Brazil [18], 85.1\% of the primary components of the B. articulate volatile profile were identified, with $93.8 \%$ of them in B. cultrate, $59.5 \%$ in B. genistifolia, and $95.3 \%$ in B. gibertii. In some cases, the compounds were identified for the first time using an experiment conducted under various abiotic and hydric conditions.

Clear differences in the qualitative and quantitative compositions among the three harvest times were observed through a comparison of EOC. The Oxygenated sesquiterpenes (OS) were more abundant in harvest 3 (Figure 2).

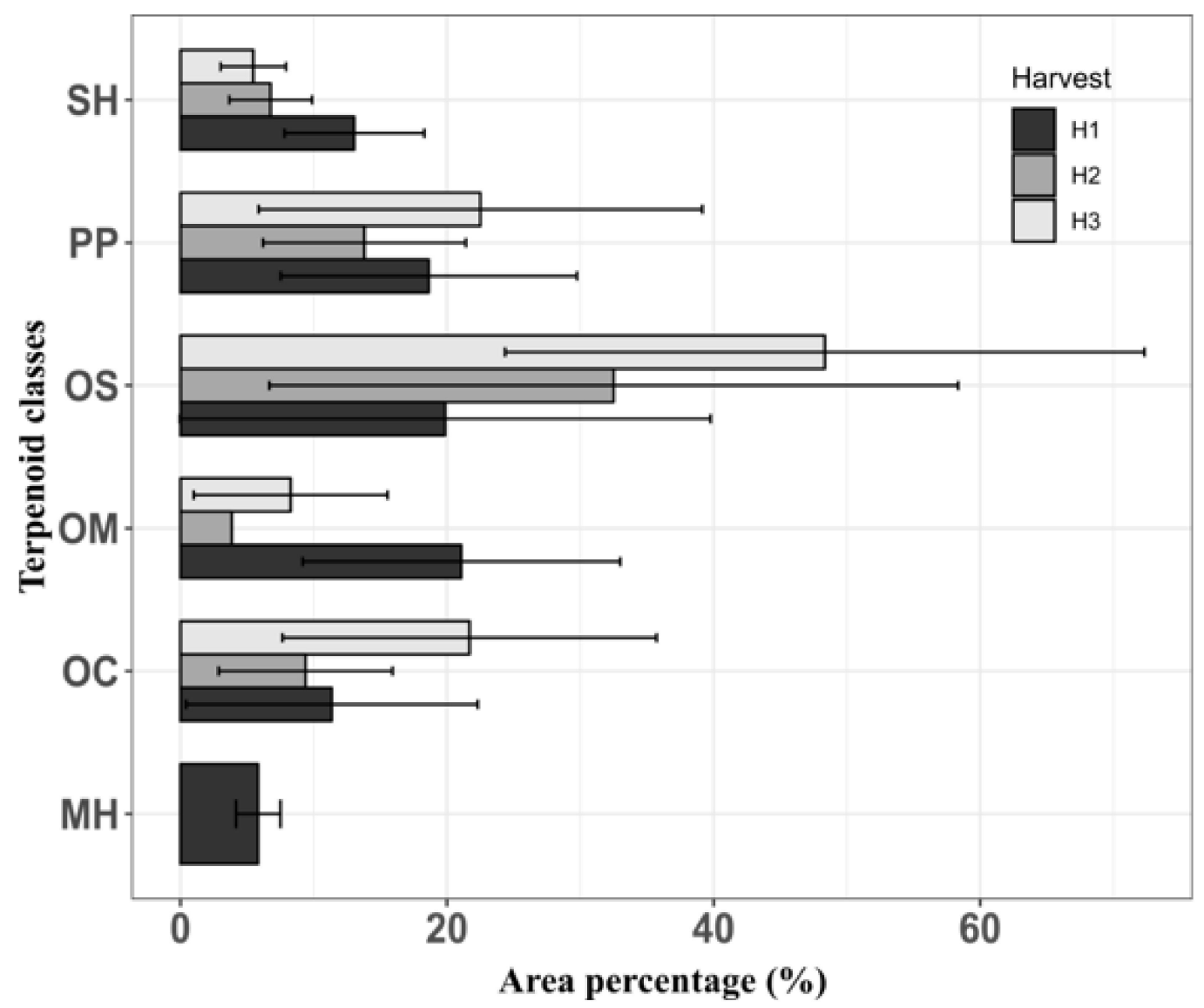

Figure 2. Relative composition (\%) of the chemical classes of volatiles in B. crispa under the three harvests H1: first harvest, $\mathrm{H} 2$ : second harvest, and H3: third harvest. SH: sesquiterpene hydrocarbons; PP: phenylpropanoids; OS: oxygenated sesquiterpenes; OM: oxygenated monoterpenes; OC: other; $\mathrm{MH}$ : monoterpene hydrocarbons.

For simplicity, the identified volatiles were grouped into six chemical classes: sesquiterpene hydrocarbons (SH), phenylpropanoids (PP), oxygenated sesquiterpenes (OS), oxygenated monoterpenes $(\mathrm{OM})$, others $(\mathrm{OC})$, and monoterpene hydrocarbons $(\mathrm{MH})$. The essential oils of B. crispa were characterized by an abundance of oxygenated sesquiterpenes (OS), which were major essential oil component (EOC) in all three harvests $(48.34 \%$ at $\mathrm{H} 3$, followed by $32.51 \%$ at $\mathrm{H} 2)$, as shown in Figure 2. 
In total, $22.51 \%$ phenylpropanoids (PP) and $21.69 \%$ of the other compounds (OC) were detected at $\mathrm{H} 3$. Sesquiterpene hydrocarbons (SH) peaked at $\mathrm{H} 1(13.05 \%)$, and monoterpene hydrocarbons ( $\mathrm{MH})$ were only detected at $\mathrm{H} 1$ (5.84\%). Other studies have revealed that essential oil can be extracted from the fresh leaves of $B$. trimera (Less) DC via steam distillation, yielding $0.05 \%$. The analyses carried out using GC-MS showed that this oil contained $4.40 \%$ monoterpenes and $80.40 \%$ sesquiterpenes [35].

Spathulenol was the first compound recorded at the highest level, and was the only oxygenated sesquiterpene found in the essential oils from all experiments-it was recorded in high levels $(95.43 \%)$ during summer (December-March) at H3 and T150 (Figure 3). The authors of [44] extracted $29.69 \%$ of B. articulata (Lam.) Pers. essential oil without grinding [41] and $16.41 \%$ B. unicella, $14.49 \%$ B. anomala, and $6.84 \%$ B. dendata essential oil in autumn through steam distillation. Oxygenated monoterpenes were recorded at $21.08 \%, 3.86 \%$, and $8.27 \%$ at $\mathrm{H} 1, \mathrm{H} 2$, and $\mathrm{H} 3$, respectively. They were dominated by 1.8-cineole (41.96\%), which was detected in winter (June-September) at H1 and T25. This value was higher than that reported in earlier analyses applied to three Baccharis species: $0.34 \%$ for B. unicella, $0.38 \%$ for B. anomala, and $0.32 \%$ for B. dendata in winter (June-September) when the essential oil was extracted through steam distillation in an experiment carried out in Southern Brazil [44]. Other compounds, such as methyl-d3 1-dideuterio-2-propenyl ether $(41.36 \%)$, were detected in winter (June-September) at H3 and T125.

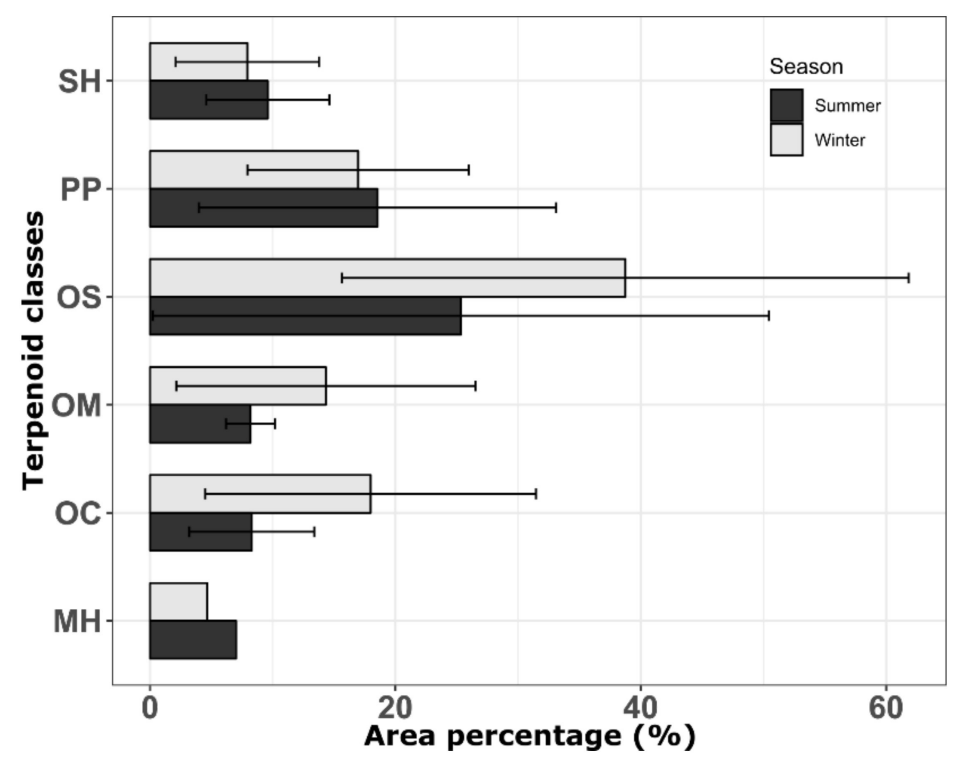

Figure 3. Distribution of chemical classes of volatiles in B. crispa during the summer (December-March) and winter (June-September) seasons. SH: sesquiterpene hydrocarbons; PP: phenylpropanoids; OS: oxygenated sesquiterpenes; OM: oxygenated monoterpenes; OC: other; $\mathrm{MH}$ : monoterpene hydrocarbons.

Eugenol $(30.19 \%)$ was the main phenylpropanoid detected in winter (June-September) at H1 and T125. This outcome is in stark contrast to the value recorded for eugenol content $(6.69 \%)$ in the essential oil of $P$. integrifolia in [45]. There was also an important difference between the ledol content at $\mathrm{H} 1$ and at T75 (10.63\%) detected during summer. The authors of [46] found a concentration of ledol equal to $13.7 \%$ in plants collected in Rio de Janeiro, Brazil, whereas the study in [5] reported a value of $1.30 \%$ in the essential oil of B. trimera (Less) DC.

Based on these results, the EOC at $\mathrm{H} 1$ showed 20.53\% oxygenated sesquiterpenes, such as caryophyllene, in winter (June-September) at T150. Costa et al. [47] found 4.0\% $\pm 1.6 \%$ caryophyllene oxide in the essential oils of Eugenia uniflora leaves collected during the dry months (April-September) in the Brazilian Cerrado. Some specific compounds were only detected when the highest rates of monoterpene hydrocarbons were obtained, for example, ascaridole $(7.02 \%)$, which was detected during 
summer at $\mathrm{H} 1$ and T150. The results of Rahman et al. [45] indicated that Premna integrifolia Linn EO featured $12.12 \%$ spathulenol, $8.21 \%$ 1-oc-ten-3-ol, $6.69 \%$ eugenol, $5.81 \%$ phenylethyl alcohol, and $2.6 \%$ caryophyllene oxide. These compounds can play key roles in antibacterial activity [48,49].

Differences between our results and the lower levels observed for other samples in the literature of less than or equal to $1.50 \%$ could be linked to the environmental conditions and time of harvest, as well as to water deficits and irrigation management [11-42]. Several studies based on Eugenia uniflora leaves show that the prevalence of factors, such as seasons, influences the prevalence of oxygenated sesquiterpenes in plants collected during all sampling months and under all chemical variations among the oils [46]. Additionally, the influence of factors such as elevation above sea level, soil type, longitude, and latitude was reflected in the prevalence of sesquiterpenes $(83.66 \%$ ) in Cordia verbanacea and Cordia leucocephala leaves [49]. Another study has also demonstrated the influence of climatic and environmental conditions on plant volatile emissions [42].

Earlier investigations also demonstrated the influence of rainfall, temperature, seasonal stress, and evapotranspiration. Harvest time may also determine the composition of essential oils [11-42,47].

\subsection{Volatile Profiles under Different Irrigation Conditions}

The volatile profiles corresponding to the six irrigation management treatments of $B$. crispa during the three harvest seasons are characterized by variations, as shown in Table S1. Table S1 (Supplementary Materials) contains details of all the identified volatile organic compounds, their retention indices, and the relative compositions of the compounds found in each sample.

In total, 21 peaks were obtained through hydrodistillation, and 48 compounds were identified. Volatile compounds ranged from $93.52 \%$ to $66.97 \%$ of the total area analyzed. These results were not in agreement with those of previous studies using Baccharis sp. leaves in which only 19 EOCs were described [7]. Spathulenol was the main compound in leaves (95.43\%) at H3 and T150 in winter (June-September), with $78.38 \%$ at $\mathrm{H} 1$ and $\mathrm{T} 50$, and $72.79 \%$ at $\mathrm{H} 2$ and $\mathrm{T} 75$, both corresponding to summer. Phthalic acid (56.82\%) at H3 and T75 was the second main compound; it was also recorded in $30.39 \%$ at H1 and T100 (winter: June-September) and 28.52\% at T100 (summer: December-March). This compound is followed by 1.8-cineole, which was the most abundant $(41.96 \%)$ in winter at H1 and T25; it was also recorded in $14.53 \%$ in winter (June-September) at H1 and T125 and $8.36 \%$ at H3 and T125 in summer. Eugenol was present in $30.19 \%$ at H1 and T125 in winter and $4.05 \%$ at $\mathrm{H} 3$ and $\mathrm{T} 125$ in summer, and linalool was recorded in $27.22 \%$ at $\mathrm{H} 1$ and T25, 8.28\% at $\mathrm{H} 1$ and T125 (both in winter: June-September), and $10.09 \%$ at H3 and T125 in summer. According to the literature, the main compounds identified in the essential oil of B. trimera under different nitrogen sources and levels formed 30 peaks: (E) caryophyllene, bicyclogermacrene, and germacrene D [35] and, common among all treatments, $\alpha$-pinene, D-limonene, caryophyllene, spathulenol, ledol, and globulol [35]. $\alpha$-Pinene, $\beta$-pinene, and spathulenol (B. uncinella); spathulenol, $\beta$-caryophyllene, and $\beta$-selinene (B. anomala); and germacrene-D, caryophyllene oxide, and spathulenol (B. dentata) were the main compounds identified via GC-MS [44].

Based on Figure 4, B. crispa leaves were rich in oxygenated sesquiterpenes $(37.00 \%)$ at T100, followed by T150 and T75. Variations in the levels of chemical volatiles, such as oxygenated sesquiterpenes (OS), were found in most treatments, with $22.35 \%$ at $\mathrm{T} 125$ and $37 \%$ at $\mathrm{T} 100$. Moreover, phenylpropanoid (PP) compounds were mostly detected at T75 (27.97\%) and were lower at T125 (13.82\%). Oxygenated monoterpenes (OM) represented around $26 \%$ in some cases. They were detected at T75 (25.31\%) and $\mathrm{T} 125(9.81 \%)$. Sesquiterpene hydrocarbons $(\mathrm{SH})$ were detected at T150 $(10.20 \%)$ and $\mathrm{T} 125(7.14 \%)$. Notably, monoterpene hydrocarbons were only observed at T150. This outcome demonstrates that increased water replacement levels can transform the presence of these compounds in the response to water excess and low oxygen content in the soil profile. The authors of [50] reported increased monoterpene concentrations under drought conditions, and the authors of [11] demonstrated that a water deficit can affect Salvia officinalis, which was shown in early investigations to contain 1.8-cineole as its main constituent $(17.86 \%)$. The water deficit increased the content of compounds such as linalool, 
menthone, and rose oxide in the EOs of Pelargonium graveolens L. and decreased geraniol and geranyl formate [43].

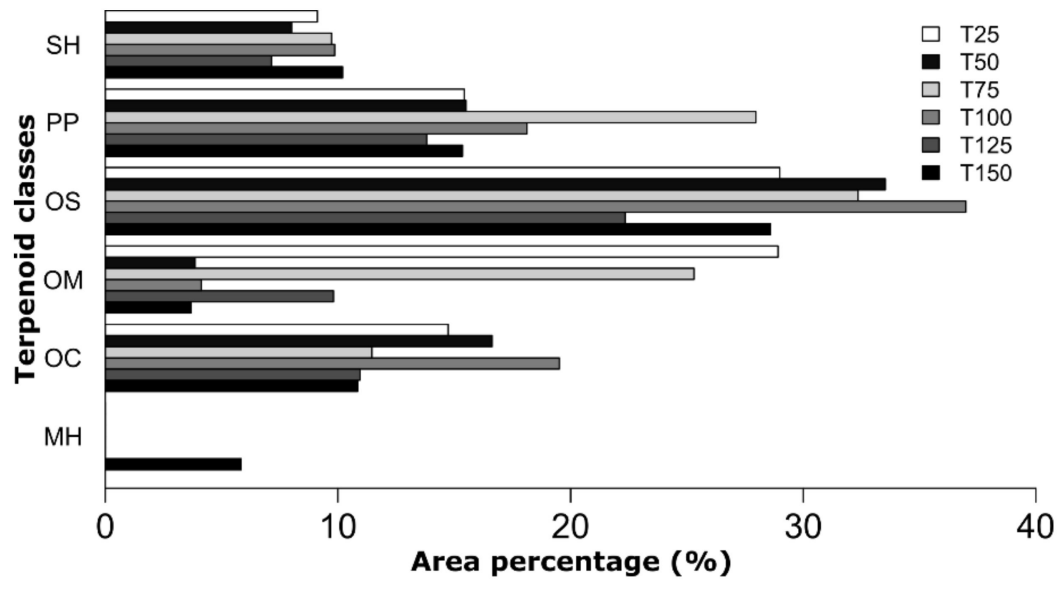

Figure 4. GC-MS grouped (\%) by chemical classes in the volatiles of B. crispa. SH: sesquiterpene hydrocarbon; PP: phenylpropanoid; OS: oxygenated sesquiterpene; OM: oxygenated monoterpene; OC: other; MH: monoterpene hydrocarbon. Treatments of irrigation regimes based on T25, T50, T75, T100, T125, T150 with values representing \% of the reference evapotranspiration (ETo).

\subsection{Multivariate Analysis}

The volatile profile of the EOC of B. crispa showed clear differences between harvest seasons and irrigation depth treatments. HCA and PCA were carried out to analyze the differences between harvest seasons and irrigation treatments. Figure 5 shows the PCA score plot used to explore the relative variability of $B$ crispa based on the harvest season.

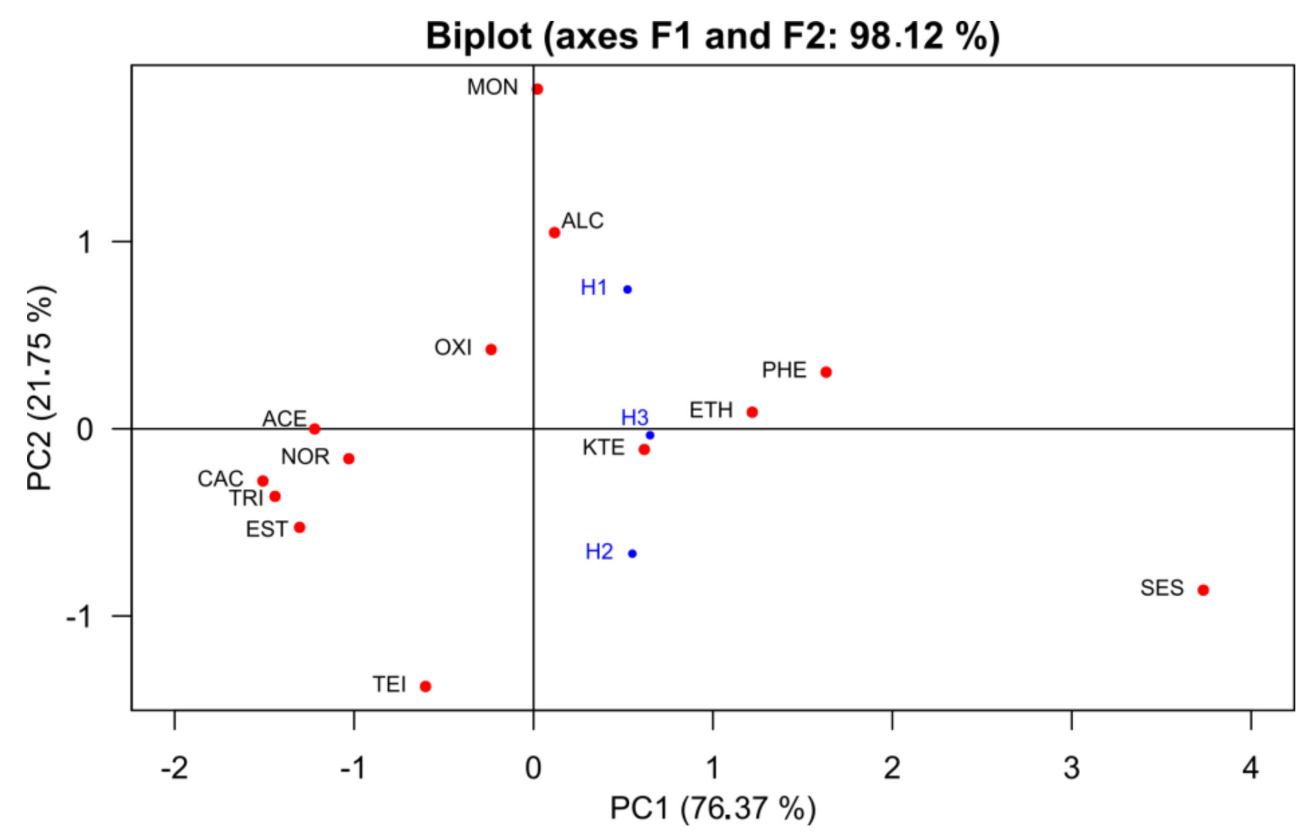

Figure 5. Principal component analysis (PCA) analysis grouped by chemical classes of B. crispa. EOS analyzed by GC-MS with respect to different harvest seasons. Ketone (KTE), monoterpenes (MO), alcohols (ALC), sesquiterpenes (SES), esters (EST), phenols (PHE), norisoprenoids (NOR), terpenoids (TEI), oxides (OXI), acetates (ACE), triterpenes (TRI), ethers (ETH), and carboxylic acids (CAC). 
The PCA accounted for $98.12 \%$ of the total variance-PC1 accounted for $76.37 \%$ and PC2 for $21.75 \%$ of the variance. The PCA results separated the harvest seasons, as shown by the formation of four well defined and clustered subgroups referring to the harvest seasons H1, H1, and H3. According to the score chart, $\mathrm{H} 1, \mathrm{H} 2$, and $\mathrm{H} 3$ lie along the positive $\mathrm{PC} 1$ axis. $\mathrm{H} 1$ is characterized by high rates of monoterpenes (MO) and alcohols (ALC), which have positive values along PC1. On the other hand, this area is positively associated with H3; the ketones (KTE), phenols (PHE), and ether (ETH), along with significant levels of sesquiterpenes (SES). PC2 showed positive associations with oxides (OXI) and acetate (ACE). Norisoprenoids (NOR), triterpene (TRI), carboxylic acid (CAC), esters (EST), and terpenoids (TEI) had negative associations with PC1 and PC2. These segregations could be due to the productivity of these chemical classes during the three harvest seasons.

The PCA chemical differences were confirmed through HCA (Figure 6). The dendrogram represents the partition hierarchies whose samples were grouped based on similarities. Group H1 was clearly and visibly separated from the groups $\mathrm{H} 2$ and $\mathrm{H} 3$. Clusters from the $\mathrm{H} 1$ groups consisted of higher-level classes of MO, ALC, and PHE than those of groups $\mathrm{H} 2$ and H3. The dendrograms also revealed that the samples from $\mathrm{H} 2$ and $\mathrm{H} 3$ were mixed to form a cluster because the profiles of their essential oils were similar.

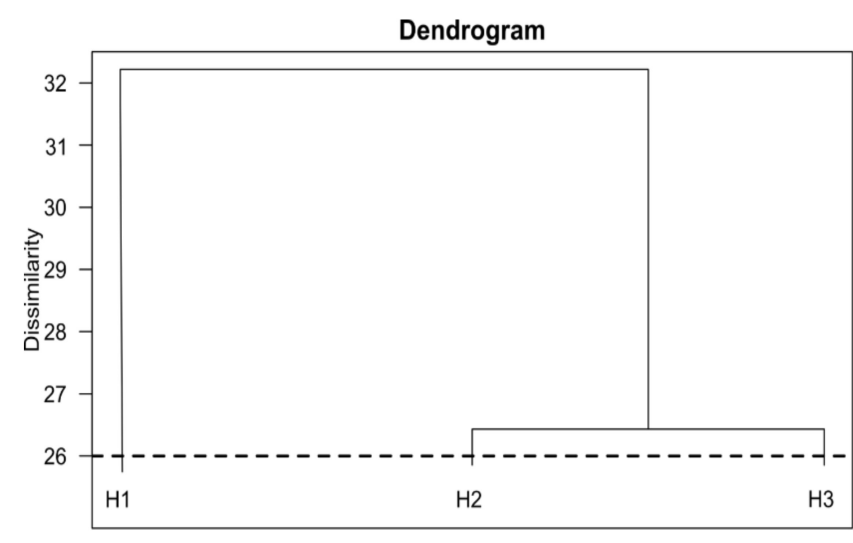

Harvest

Figure 6. Dendrogram obtained from the cluster analysis of the relative dissimilarity in compounds according to the chemical classes based on the samples analyzed by GC-MS and grouped by harvest.

Regarding the behavior of the irrigation depth treatments, PCA accounted for $88.26 \%$ of the total variance, PC1 accounted for $74.87 \%$, and PC2 accounted for $13.39 \%$. The PCA results showed separation according to the harvest season. This outcome was revealed by the formation of four well defined and clustered subgroups with respect to T25, T50, T75, T100, T125, and T150. The score chart shows that T25, T50, T75, T100, T125, and T150 were aligned with the positive PC1 axis. T100 and T50 were characterized by high percentages of ether (ETH), phenols (PHE), and oxides (OXI), and significant sesquiterpene (SES) levels at T75, T150, T25, and T125. OXI had a negative association with PC2. PC2, in turn, was positively associated with monoterpenes (MO), alcohols (ALC), ketones (KTEs), and terpenoids (TEIs). Acetates (ACE), norisoprenoids (NOR), triterpenes (TRI), carboxylic acids (CAC), and esters (EST) were negatively associated with PC1 and PC2 (Figure 7).

Figure 6 exhibits a dendrogram obtained from the cluster analysis based on the relative dissimilarity in compounds according to the chemical classes of B. crispa. T100 was clearly and visibly separated from the groups $\mathrm{H} 2$ and $\mathrm{H} 3$. The clusters from group $\mathrm{H} 1$ consisted of higher-level classes of MO, ALC, and PHE compared to groups $\mathrm{H} 2$ and $\mathrm{H} 3$. This figure also shows that the samples from $\mathrm{H} 2$ and $\mathrm{H} 3$ were mixed to form a cluster because the profiles of their essential oils were similar.

Figure 7 shows that T25 and T125 were combined to form a cluster. Regardless of the irrigation regimes based on ETo, the clusters linked to T75, T150, and T50 did not show major differences between 
their chemical classes (Figure 6). These results established an obvious difference in the quality and number of secondary metabolites controlled by the harvest season and irrigation regimes.

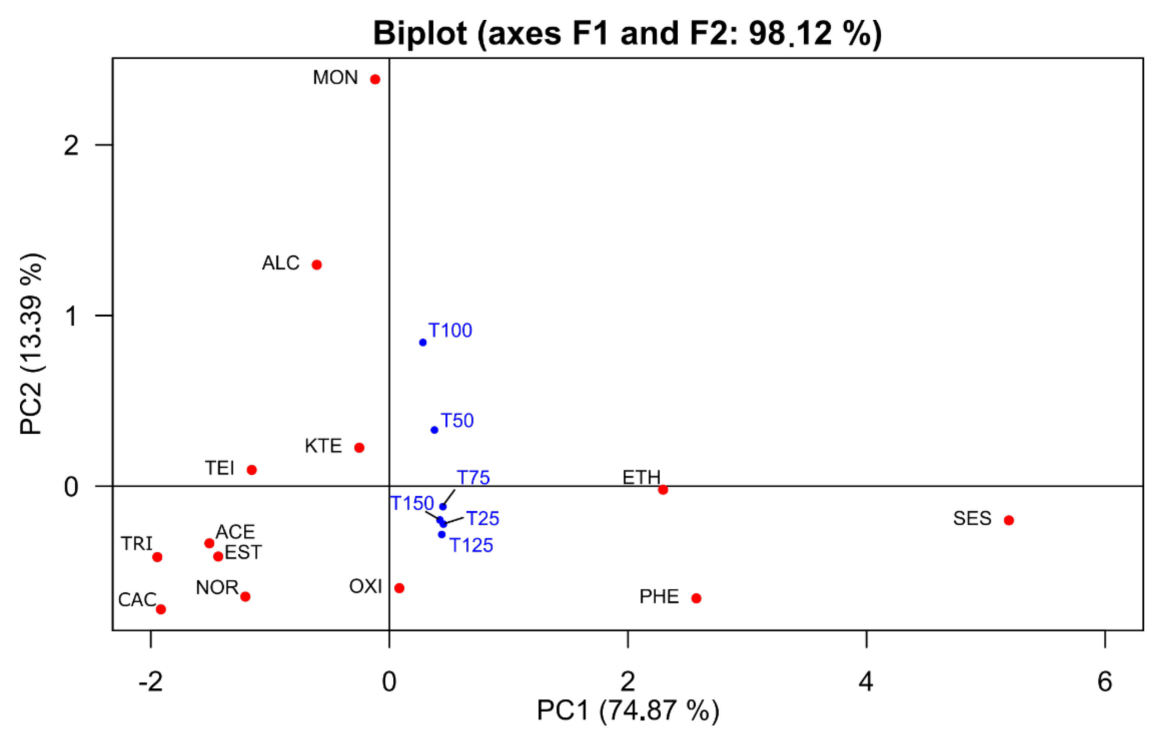

Figure 7. Principal component analysis (PCA) analysis grouped by chemical classes of B. crispa. Essential Oils (Eos) extracted by GC-MS with respect to different irrigation treatments. Ketones (KTE), monoterpenes (MO), alcohols (ALC), sesquiterpenes (SES), esters (EST), phenols (PHE), norisoprenoids (NOR), terpenoids (TEI), oxides (OXI), norisoprenoids (NOR), acetates (ACE), triterpenes (TRI), ethers (ETH), and carboxylic acids (CAC).

\section{Conclusions}

We found an abundance of sesquiterpenes in the leaf oils extracted via hydrodistillation from a Baccharis species. To the best of our knowledge, we are the first to discover the presence of the following compounds in B. crispa: allyl $\alpha$-ionone, retinol, naphthalenyl, linalool, camphor, ascaridole, 9.10-dimethyl-tricyclo[4.2.1.1 2.5]decane-9.10-diol, eugenol, butanoic-acid, 2-heptanone, phtalicacid, 3-hydroxy-3.6-dimethyl-6-[3-(1-methylethenyl)-1-cyclopropen-1-yl], ethanone, naphthalenol, 9-(3,3-dimethyl-2-oxiranyl)-2,7-dimethyl-2,6-nonadien-1-ol, ergostane, methyl-propenyl-ether, tricyclo[5.1.0.0(2,4)]octane-5-carboxylic acid, 3,3,8,8-tetramethyl, acetone, 1.8-cineole, linalool, camphor, carotol, hinesol, and oxabicyclo. These compounds have demonstrated activities against gastrointestinal inflammation in addition to antioxidant, antimalarial activity, anticancer, and analgesic properties. The environment and soil water availability can change the essential oil content of B. crispa. Harvest seasons were clearly differentiable due to their qualitative chemistry. The volatile profiles and the specific features needed to separate the essential oil components (EOCs) from the leaves of B. crispa were achieved using GC-MS. The chemical classes featuring EOCs separated from leaves were different between harvest seasons and irrigation regimes (treatments). Oxygenated sesquiterpenes, phenylpropanoids (PP), and oxygenated monoterpenes were the primary chemical classes and are commonly known as preservative and antifungal agents. Based on these results, cultivation under the applied conditions in a greenhouse in Piracicaba, SP, Brazil could maximize the production of spathulenol, 1.8-cineole, and eugenol under irrigation and harvest time management. Spathulenol was the main compound in leaf EOs in all treatments. Phthalic acid and 1.8-cineole were the second most important compounds at early harvest (H1) and T50 and at H2 and T75 (deficit irrigation regime), respectively. Eugenol was the primary compound at H1 and T125 in winter (June-September) and at late harvest (H3) and T125 (excess irrigation regimes) in summer (December-March); linalool was the main compound at $\mathrm{H} 1$ and T25 and $\mathrm{H} 1$ and T125 in winter and at H3 and T125 in summer. These results will be useful for defining the conditions ultimately influencing the essential oil profile of cultivated B. crispa and to achieve better agronomic management for commercial purposes. 
Supplementary Materials: The following are available online at http://www.mdpi.com/2624-7402/2/3/31/s1: Table S1: Linear retention indices and percentage of the area present in the mass spectra of volatile compounds in B. crispa identified by GC-MS (1st Harvest). Table S2: Linear retention indices and percentage of the area present in the mass spectra of volatile compounds in B. crispa identified by GC-MS (2nd Harvest). Table S3: Linear retention indices and percentage of the area present in the mass spectra of volatile compounds in $B$. crispa identified by GC-MS (3rd Harvest).

Author Contributions: Conceptualization, M.A.M.-P.; data curation, M.A.M.-P. and S.M.D.S.P.; formal analysis, M.A.M.-P., F.J.P.-T., A.J.F.-R., H.T.d.S., A.P.M., F.R.M., and B.Y.T.; investigation, M.A.M.-P., P.A.A.M., and S.M.d.A.; methodology, B.Y.T., S.M.D.S.P., and S.M.d.A.; software, B.Y.T.; supervision, P.A.A.M.; validation, M.A.M.-P., F.J.P.-T., A.J.F.-R., H.T.d.S., A.P.M., F.R.M., and S.M.D.S.P.; visualization, P.A.A.M. and S.M.d.A.; writing-original draft, M.A.M.-P.; and writing—review and editing, M.A.M.-P., F.J.P.-T., A.J.F.-R., H.T.d.S., A.P.M., F.R.M., and S.M.D.S.P. All authors have read and agreed to the published version of the manuscript.

Funding: This research was funded by the Coordination of Improvement of Higher Education Personnel (CAPES), Finance Code 001; the National Council for Scientific and Technological Development (CNPq), Finance Code 161398/2014-6; and (CNPq) grants 425174/2018-2.

Acknowledgments: The National Institute of Science and Technology-INCTEI Irrigation Engineering of the Department of Biosystems Engineering of ESALQ, for the equipment used in this experiment.

Conflicts of Interest: The authors declare no conflict of interest.

\section{References}

1. Dos Santos, D.A.; Fukui, M.D.J.; Nanayakkara, N.D.; Khan, S.I.; Sousa, J.P.B.; Bastos, J.K.; De Andrade, S.F.; Filho, A.A.D.S.; Quintão, N.L. Anti-inflammatory and antinociceptive effects of Baccharis dracunculifolia DC (Asteraceae) in different experimental models. J. Ethnopharmacol. 2010, 127, 543-550. [CrossRef] [PubMed]

2. Nogueira, N.; Reis, P.; Laranja, G.; Pinto, A.; Aiub, C.; Felzenszwalb, I.; Paes, M.; Bastos, F.; Bastos, V.; Sabino, K.; et al. In vitro and in vivo toxicological evaluation of extract and fractions from Baccharis trimera with anti-inflammatory activity. J. Ethnopharmacol. 2011, 138, 513-522. [CrossRef] [PubMed]

3. Ferreira, P.d.A. Desenvolvimento de Forma Farmacêutica Sólida à Base de Baccharis trimera (Less.) DC. Para o Tratamento da Artrite Reumatóide. Master's Thesis, Universidade Federal de Pernambuco, Recife, Brazil, 2012.

4. Verdi, L.G.; Brighente, I.M.C.; Pizzolatti, M.G. Gênero Baccharis (Asteraceae): Aspectos químicos, económicos e biológicos. Química Nova 2005, 28, 85-94. [CrossRef]

5. De Oliveira, R.N.; Rehder, V.L.G.; Santos Oliveira, A.S.; Júnior, Í.M.; de Carvalho, J.E.; de Ruiz, A.L.T.G.; Sierpe Jeraldo, V.d.L.; Linhares, A.X.; Allegretti, S.M. Schistosoma mansoni: In vitro schistosomicidal activity of essential oil of Baccharis trimera (Less) DC. Exp. Parasitol. 2012, 132, 135-143. [CrossRef]

6. Silva, F.G.; Oliveira, C.; Pinto, J.E.B.; Nascimento, V.E.; Santos, S.C.; Seraphin, J.C.; Ferri, P.H. Seasonal variability in the essenial oils of wild and cultivated Baccharis trimera. J. Braz. Chem. Soc. 2007, 18, 990-997. [CrossRef]

7. De Oliveira, R.N.; Rehder, V.L.G.; Oliveira, A.S.S.; Jeraldo, V.d.L.S.; Linhares, A.X.; Allegretti, S.M. Anthelmintic activity in vitro and in vivo of Baccharis trimera (Less) DC. against immature and adult worms of Schistosoma mansoni. Exp. Parasitol. 2014, 139, 63-72. [CrossRef]

8. Zunino, M.P.; Newton, M.N.; Maestri, D.M.; Zygadlo, J.A. Essential oils of three Baccharis species. Planta Med. 1998, 64, 86-87. [CrossRef]

9. De Bona, C.M.; Biasi, L.A.; Zanette, F.; Nakashima, T. Estaquia de três espécies de Baccharis. Ciênc. Rural 2005, 35, 223-226. [CrossRef]

10. Letchamo, W.; Xu, H.L.; Gosselin, A. Variations in photosynthesis and essential oil in thyme. J. Plant Physiol. 1995, 147, 29-37. [CrossRef]

11. Bettaieb, I.; Zakhama, N.; Wannes, W.A.; Kchouk, M.E.; Marzouk, B. Water deficit effects on Salvia officinalis fatty acids and essential oils composition. Sci. Hortic. 2009, 120, 271-275. [CrossRef]

12. Rioba, N.B.; Itulya, F.M.; Saidi, M.; Dudai, N.; Bernstein, N. Effects of nitrogen, phosphorus and irrigation frequency on essential oil content and composition of sage (Salvia officinalis L.). J. Appl. Res. Med. Aromat. Plants 2015, 2, 21-29. [CrossRef]

13. Polanía Perdomo, J.A.; Rivera, M.; Ricaurte, J.; Rao, I.M. Phenotyping Common Beans for Adaptation to Drought: Protocol for Greenhouse Evaluation; International Center for Tropical Agriculture: Cali, Colombia, 2012. 
14. Putievsky, E.; Ravid, U.; Dudai, N. The influence of season and harvest frequency on essential oil and herbal yields from a pure clone of sage (Salvia officinalis) grown under cultivated conditions. J. Nat. Prod. 1986, 49, 326-329. [CrossRef]

15. Verma, R.S.; Padalia, R.C.; Chauhan, A.; Upadhyay, R.K.; Singh, V.R. Productivity and essential oil composition of rosemary (Rosmarinus officinalis L.) harvested at different growth stages under the subtropical region of north India. Essent. Oil Res. 2019, 32, 144-149. [CrossRef]

16. Kaltsa, O.; Grigorakis, S.; Lakka, A.; Bozinou, E.; Lalas, S.; Makris, D.P. Green Valorization of Olive Leaves to Produce Polyphenol-Enriched Extracts Using an Environmentally Benign Deep Eutectic Solvent. AgriEngineering 2020, 2, 14. [CrossRef]

17. Giannoulis, K.D.; Kamvoukou, C.-A.; Gougoulias, N.; Wogiatzi, E. Irrigation and nitrogen application affect Greek oregano (Origanum vulgare ssp. hirtum) dry biomass, essential oil yield and composition. Ind. Crops Prod. 2020, 150, 112392. [CrossRef]

18. Minteguiaga, M.; González, A.; Cassel, E.; Umpierrez, N.; Fariña, L.; Dellacassa, E. Volatile constituents from Baccharis spp. L. (Asteraceae): Chemical support for the conservation of threatened Species in Uruguay. Chem. Biodivers. 2018, 15, e1800017. [CrossRef]

19. Embrapa Informação Tecnológica. Sistema Brasileiro de Classificação de Solos. Available online: www.cnps. embrapa.br/sac (accessed on 9 May 2016).

20. United States Department of Agriculture NRCS; Soil Survey Staff. GNATSGO (Gridded National Soil Survey Geographic). Available online: https://nrcs.app.box.com/v/soils (accessed on 20 February 2020).

21. Allen, R.G.; Pereira, L.S.; Raes, D.; Smith, M. Crop Evapotranspiration-Guidelines for Computing Crop Water Requirements-FAO Irrigation and Drainage Paper; FAO: Rome, Italy, 1998; Volume 300, p. D05109.

22. Asensio, C.M.; Grosso, N.R.; Juliani, H.R. Quality preservation of organic cottage cheese using oregano essential oils. LWT Food Sci. Technol. 2015, 60, 664-671. [CrossRef]

23. Clevenger, J.F. Apparatus for volatile oil determination, Description of New Type. Am. Perfum. Essent. Oil Rev. 1928, 17, 467-503.

24. Ferhat, M.A.; Meklati, B.Y.; Smadja, J.; Chemat, F. An improved microwave Clevenger apparatus for distillation of essential oils from orange peel. J. Chromatogr. A 2006, 1112, 121-126. [CrossRef]

25. Gavahian, M.; Farahnaky, A.; Javidnia, K.; Majzoobi, M. Comparison of ohmic-assisted hydrodistillation with traditional hydrodistillation for the extraction of essential oils from Thymus vulgaris L. Innov. Food Sci. Emerg. Technol. 2012, 14, 85-91. [CrossRef]

26. El Gendy, A.; Leonardi, M.; Mugnaini, L.; Bertelloni, F.; Ebani, V.; Nardoni, S.; Mancianti, F.; Hendawy, S.; Omer, E.; Pistelli, L. Chemical composition and antimicrobial activity of essential oil of wild and cultivated Origanum syriacum plants grown in Sinai, Egypt. Ind. Crop. Prod. 2015, 67, 201-207. [CrossRef]

27. Cazella, L.N.; Glamoclija, J.; Soković, M.; Gonçalves, J.E.; Linde, G.A.; Colauto, N.B.; Gazim, Z.C. Antimicrobial activity of essential oil of Baccharis dracunculifolia DC. (Asteraceae) aerial parts at flowering period. Front. Plant Sci. 2019, 10, 27. [CrossRef] [PubMed]

28. Acevedo, F.; Torres, P.; Oomah, B.D.; De Alencar, S.M.; Massarioli, A.P.; Martin-Venegas, R.; Albarral-Ávila, V.; Burgos-Díaz, C.; Ferrer, R.; Rubilar, M. Volatile and non-volatile/semi-volatile compounds and in vitro bioactive properties of Chilean Ulmo (Eucryphia cordifolia Cav.) honey. Food Res. Int. 2017, 94, $20-28$. [CrossRef] [PubMed]

29. R Core Team. R: A Language and Environment for Statistical Computing. Available online: http: //www.r-project.org (accessed on 29 February 2020).

30. Yu, G.; Wang, L.-G.; Han, Y.; He, Q.-Y. clusterProfiler: An R package for comparing biological themes among gene clusters. OMICS J. Integr. Boil. 2012, 16, 284-287. [CrossRef]

31. Fachinello, J.C.; da Silveira Pasa, M.; Schmtiz, J.D.; Betemps, D.L. Situação e perspectivas da fruticultura de clima temperado no Brasil. Rev. Bras. Frutic. 2011, 33, 109-120. [CrossRef]

32. Andrião, M.A. Marcha de absorção de macronutrientes e acúmulo de fenólicos totais em [(Baccharis trimera (Less.) DC.] var. CPQBA-1, Sob Diferentes Podas no Plantio. Master's Thesis, Universidade Estadual Paulista "Julio de Mesquita Filho" (UNESP), Botucatu, Brazil, 2010.

33. Burmeister, J.; Guttenberg, H.V. Die ätherischen öle als produkt eines partiell anaeroben stoffwechsels. Planta Med. 1960, 8, 1-33. [CrossRef] 
34. García, D. Desenvolvimento, Rendimento, Teor e Componentes do Óleo Essencial em Função de Adubação Orgânica e Rebroto de Baccharis trimera (Less.) DC. cv. CPQBA-1. Master's Thesis, Universidade Estadual Paulista "Julio de Mesquita Filho" (UNESP), Botucatu, Brazil, 2013.

35. Palácio, C.P.A.M.; Biasi, L.A.; Nakashima, T.; Serrat, B.M. Biomassa e óleo essencial de carqueja (Baccharis trimera (Less.) DC.) sob influência de fontes e doses de nitrogênio. Rev. Bras. Plantas. Med. 2007, 9, 58-63.

36. Budel, J.M.; Duarte, M.R.; Santos, C.A.M. Stem morpho-anatomy of Baccharis cylindrica (Less) DC. (Asteraceae). Rev. Bras. Ciênc. Farm. 2004, 40, 93-99. [CrossRef]

37. Bogo, C.A.; Andrade, M.H.; Paula, J.P.; Farago, P.V.; Döll-Boscardin, P.M.; Budel, J.M. Comparative analysis of essential oils of Baccharis L.: A review. Rev. Strict. Sensu. 2016, 1, 1-11. [CrossRef]

38. Budel, J.M.; Wang, M.; Raman, V.; Zhao, J.; Khan, S.I.; Rehman, J.U.; Techen, N.; Tekwani, B.; Monteiro, L.M.; Heiden, G.; et al. Essential oils of five baccharis species: Investigations on the chemical composition and biological activities. Molecules 2018, 23, 2620. [CrossRef]

39. Siqueira, N.; Thiesen, F.V.; Alice, C.B. Aspectos farmacognósticos e perfil cromatográfico dos constituintes de Bacharis articulata Lam. Pers. Compositae. Cad. Farm. Porto Alegre RS 1988, 4, 63-67.

40. Fachinetto, J.M.; Tedesco, S.B. Atividade antiproliferativa e mutagênica dos extratos aquosos de Baccharis trimera (Less.) AP de Candolle e Baccharis articulata (Lam.) Pers.(Asteraceae) sobre o sistema teste de Allium cepa. Rev. Bras. Plantas Med. 2009, 11,360-367. [CrossRef]

41. Tischer, B.; Vendruscolo, R.G.; Wagner, R.; Menezes, C.R.; Giacomelli, S.R.; Budel, J.M.; Barin, C.S.; Barin, J.S. Effect of grinding method on the analysis of essential oil from Baccharis articulata (Lam). Pers. Chem. Pap. 2017, 71, 753-761. [CrossRef]

42. Zribi, I.; Bleton, J.; Moussa, F.; Abderrabba, M. GC-MS analysis of the volatile profile and the essential oil compositions of Tunisian Borago Officinalis L.: Regional locality and organ dependency. Ind. Crop. Prod. 2019, 129, 290-298. [CrossRef]

43. Amiri, R.; Nikbakht, A.; Rahimmalek, M.; Hosseini, H. Variation in the Essential Oil Composition, Antioxidant Capacity, and Physiological Characteristics of Pelargonium graveolens L. Inoculated with Two Species of Mycorrhizal Fungi Under Water Deficit Conditions. J. Plant Growth Regul. 2017, 36, 502-515. [CrossRef]

44. Xavier, V.; Vargas, R.; Cassel, E.; Lucas, A.; Santos, M.; Mondin, C.; Santarém, E.; Astarita, L.V.; Sartor, T. Mathematical modeling for extraction of essential oil from Baccharis spp. by steam distillation. Ind. Crop. Prod. 2011, 33, 599-604. [CrossRef]

45. Rahman, A.; Shanta, Z.S.; Rashid, M.; Parvin, T.; Afrin, S.; Khatun, M.K.; Sattar, M. In vitro antibacterial properties of essential oil and organic extracts of Premna integrifolia Linn. Arab. J. Chem. 2016, 9, S475-S479. [CrossRef]

46. Morais, L.A.S.; Castanha, R.F. Composição química do óleo essencial de duas amostras de carqueja (Baccharis sp.) coletadas em Paty do Alferes-Rio de Janeiro. Rev. Bras. Plantas Med. 2011, 13, 628-632. [CrossRef]

47. Costa, D.P.; Santos, S.C.; Seraphin, J.C.; Ferri, P.H. Seasonal variability of essential oils of eugenia uniflora leaves. J. Braz. Chem. Soc. 2009, 20, 1287-1293. [CrossRef]

48. Sartoratto, A.; Machado, A.L.M.; Delarmelina, C.; Figueira, G.M.; Duarte, M.C.T.; Rehder, V.L.G. Composition and Antimicrobial Activity of Essential Oils From Aromatic Plants Used in Brazil. Braz. J. Microbiol. 2004, 35, 275-280. [CrossRef]

49. Rodrigues, F.F.G.; Oliveira, L.G.S.; Rodrigues, F.F.G.; Saraiva, M.E.; Almeida, S.C.X.; Cabral, M.E.S.; Campos, A.R.; Costa, J.G.M. Chemical composition, antibacterial and antifungal activities of essential oil from Cordia verbenacea DC. leaves. Pharmacogn. Res. 2012, 4, 161-165. [CrossRef] [PubMed]

50. Novak, J.; Lukas, B.; Franz, C. Temperature influences thymol and carvacrol differentially in Origanum spp.(Lamiaceae). J. Essent. Oil Res. 2010, 22, 412-415. [CrossRef]

(C) 2020 by the authors. Licensee MDPI, Basel, Switzerland. This article is an open access article distributed under the terms and conditions of the Creative Commons Attribution (CC BY) license (http://creativecommons.org/licenses/by/4.0/). 